\title{
THE OCCURRENCE OF Fusarium spp. ON OAT (Avena sativa L.) AND SUSCEPTIBILITY OF SEEDLINGS OF SELECTED GENOTYPES TO INFECTION WITH Fusarium graminearum SCHWABE
}

\author{
Irena Kiecana, Elżbieta Mielniczuk, \\ Małgorzata Cegiełko, Alina Pastucha \\ Department of Phytopathology and Mycology, University of Life Sciences in Lublin \\ Leszczyńskiego 7, 20-069 Lublin, Poland \\ e-mail: irena.kiecana@up.lublin.pl
}

Received: 08.11.2013

\begin{abstract}
The present study was carried out in the years 2010-2012 in the fields of the Strzelce Plant Breeding Company Ltd., belonging to the Plant Breeding and Acclimatization Institute in Radzików, and it included 39 oat genotypes. At the six-week seedling stage, the percentage of plants with root and leaf sheath necrosis symptoms was evaluated. In 2010 the percentage of seedlings with disease symptoms ranged from $6.5 \%$ to $25 \%$, in 2011 it ranged from $17 \%$ to $34.5 \%$, whereas in 2012 from $10 \%$ to $25 \%$. In 2010 the disease index ranged from 1.4 to 5.7 , in 2011 from 4.5 to 8.8 , while in 2012 it was between 2.0 and 5.4 .

Mycological analysis showed that large numbers of Fusarium spp. colonies were obtained both from the roots and leaf sheaths. Isolates of these fungi accounted for $63.48 \%$ of the total fungi isolated from seedlings. Seedlings grown under the conditions of central Poland were damaged by the species $F$. culmorum, $F$. avenaceum, and $F$. solani. The investigation of the susceptibility of 15 oat genotypes to infection with two Fusarium graminearum strains - Tz 56 and Tk 235 - was carried out under growth chamber conditions at a temperature of $22-23^{\circ} \mathrm{C}$ and relative air humidity of $85 \%$. The $F$. graminearum strain $\mathrm{Tz} 56$ proved to be the most pathogenic to seedlings of the breeding lines STH 0.9403 and POB 1316/08, for which the disease index was 80.5 and 75.5, respectively. The lowest pathogenicity of the a.m. strain was recorded in the case of the genotype DC 1832/05, for which the disease index was 26.5 . The $F$. graminearum strain Tk 235 proved to be the most pathogenic to the genotypes STH 0.9403 and STH 0.9423, for which the disease index was 70.5 and 70.0, respectively, whereas this strain was least pathogenic to the breeding line DC 2112/05, in the case of which the disease index was 25.5.
\end{abstract}

Key words: Avena sativa, genotypes, seedling damping-off, susceptibility, Fusarium graminearum

\section{INTRODUCTION}

Due to the introduction of reduced tillage systems, the problem of infection of seedlings as well as of the roots and stem base of cereals with fungi of the genus Fusarium is gaining special importance [1, 2, 3, $4,5]$. The oat is considered to be a species that produces good yields in crop rotations with a large proportion of cereals, but it is infected by fungi of the genus Fusarium, one of the components causing root and stem rot diseases $[6,1] . F$. culmorum and $F$. avenaceum have been recognized as the main cause of these diseases in oat crops [7, 1, 2]. These fungi are distinguished by abundant conidial sporulation. Macroconidia of these fungi are formed in sporodochia developing in crop residue on the soil surface [8]. The above-mentioned Fusarium species are also characterized by high tolerance to temperature and humidity $[1,9]$. Moreover, seedlings and the stem base of cereals are damaged by the species $F$. graminearum; seed material is thought to be the main source of primary infection of cereal seedlings with this fungus $[10,11,12,13]$. The species $F$. avenaceum (teleomorph: Gibberella avenacea) and $F$. graminearum (teleomorph: G. zeae) form on cereal crop residue and on the lower nodes of the stem base perithecia containing ascospores, which are carried by the wind for long distances [12, 14, 15].

The aim of the present study was to determine the contribution of fungi of the genus Fusarium to the infection of oat seedlings grown under the conditions of central Poland as well as to determine the pathogenicity of $F$. graminearum to seedlings of several oat genotypes under controlled temperature and humidity conditions. 


\section{MATERIALS AND METHODS}

The study on the occurrence of Fusarium spp. on oat was conducted in the years 2010-2012 in the fields of the Strzelce Plant Breeding Company Ltd., belonging to the Plant Breeding and Acclimatization Institute in Radzików. 15 oat genotypes were included in the study each year and a total of 39 genotypes were investigated (a list of cultivars and breeding lines is shown in Table 1). At the six-week seedling stage, 200 (4x50) seedlings of each genotype were sampled. The sampling method was the same as the one used in the study of oat conducted by $\mathrm{K} \mathrm{i} \mathrm{e} \mathrm{c} \mathrm{a} \mathrm{n}$ a et al. [1].

The percentage of plants with root and leaf sheath necrosis symptoms was evaluated in a laboratory using a five-point scale and the disease index was calculated in the same way as in the study of oat conducted by Kie c a n a et al. [2]. The obtained results were statistically analyzed using T-Tukey's confidence half-intervals [16].

Subsequently, a mycological analysis of the diseased plants was performed. The number of pieces of seedlings collected for analysis and the analysis method were the same as in the study by $\mathrm{Ki}$ e $\mathrm{c}$ a $\mathrm{n}$ a and Mielniczuk [7]. The cultures of Fusarium spp. were identified to the species level using monographs and keys by Kwaśna et al. [17] and Leslie and $\mathrm{S}$ u m merell [18].

The infection experiment to evaluate the susceptibility of seedlings of 15 oat genotypes to infection by Fusarium graminearum No. Tz 56 obtained from kernels and with $F$. graminearum No. Tk 235 isolated from the roots was conducted in a growth chamber at a temperature of $23-24^{\circ} \mathrm{C}$ and relative air humidity of $85 \%$. The strains whose pathogenicity had been earlier tested in the laboratory by the method of $\mathrm{Mishra}$ and Behr [19] were used in the investigation. 14-day-old cultures of $F$. graminearum grown on PDA medium in Petri dishes at $22^{\circ} \mathrm{C}$ were used as fungal inoculum.

Kernels of the analyzed oat genotypes whose sprouts had reached a length of $10 \mathrm{~mm}$ and were normally developed were selected for the investigation of susceptibility. The selected material was placed on a PDA layer with the studied fungal strains, which were in plastic pots with a diameter of $10 \mathrm{~cm}$ and a height of $15 \mathrm{~cm}$ filled with all-purpose growing medium with an addition of sand at a 2:1 ratio and a $\mathrm{pH} 6.5$, previously sterilized twice in an autoclave for two hours at $121^{\circ} \mathrm{C}$ and then covered with the medium [20]. Pots in which sprouted kernels were placed on layers of PDA medium without fungus were the control. The experiment was established on 4 May 2012 and was performed in four replicates with 25 plants per replicate. Plants grew for 24 days and then the degree of infection of seedlings was determined using a four-point scale and the disease index was calculated in the same way as in the study by Kiecan a and Kocyłak [21]. The results were statistically analyzed in the same way as in the case of plants collected from plantations.

Ten seedlings with disease symptoms from each treatment of the growth chamber experiment were designated for mycological analysis, which was carried out in the same way as in the case of plants grown under field conditions. The cultures of fungi were identified to the species using monographs and keys $[22,23$, $24,25,26,27]$.

\section{RESULTS}

Spring observations revealed the occurrence of oat seedlings with root and leaf sheath necrosis. In 2010 the percentage of plants with disease symptoms varied from $6.5 \%$ (POB 648/06) to $25 \%$ (CHD 2316/03) (Fig. 1), in 2011 from 17\% (STH 9110) to $34.5 \%$ (STH 9410) (Fig. 2), whereas in 2012 from 10\% (POB 4129-4416/11) to 25\% (DC 3674/02) (Fig. 3). In 2010 the significantly highest disease index was observed in the case of the breeding line CHD 2316/03 (5.7), whereas the significantly lowest value was found in the breeding line POB 648/06 (1.4) (Table 1). In 2011 the significantly highest disease index was recorded in the case of the genotype DC 1329/05 (8.8), while the significantly lowest index was found for the genotypes Nagus (4.5) and POB 1882/09 (4.7). In 2012 the significantly highest disease index was found in the case of the following genotypes: DC 3674/02 (5.7), DC 2112/05 (5.4), STH 0.8124 (5.3), and POB $2885 / 08$ (5.3), whereas the significantly lowest value was found in the breeding line POB 4129-4416/11 (2.0) (Table 1).

The mycological analysis showed that large numbers of Fusarium species were obtained both from the roots and leaf sheaths. On average for the three-year study period, isolates of these fungi accounted for $63.48 \%$ of total isolates from oat seedlings. Among pathogenic species, the following were isolated from seedlings: F. culmorum, whose isolates accounted for $19.84 \%$ of total isolations, $F$. solani $(6.70 \%$ of all fungi obtained from seedlings), $F$. avenaceum $(7.04 \%)$, $F$. sporotrichioides $(2.22 \%), F$. equiseti $(2.30 \%)$, $F$. graminearum $(1.39 \%)$, and $F$. crookwellense $(0.08 \%)$. Moreover, $F$. oxysporum $(21.76 \%$ of all fungi) and $F$. poae (2.15\% of total isolates) were isolated from oat seedlings (Table 2).

The study in the growth chamber showed that plants with disease symptoms occurred in the experimental treatments with oat kernels infected with both Fusarium graminearum $\mathrm{Tz} 56$ and $F$. graminearum Tk 235. Plant losses caused by pre- and post-emergence damping-off were recorded in the case of both 
investigated $F$. graminearum strains. Infected plants were characterized by root and hypocotyl necrosis and quite often by hypocotyl contraction and root reduction. Furthermore, infected oat seedlings showed inhi- bited growth and yellowing leaves. Control seedlings of the tested genotypes did not exhibit distinct disease symptoms; they had a well-developed root system and root necrosis was observed sporadically.

Table 1

Mean values of the disease index for seedlings of the tested oat genotypes grown under field conditions in 2010-2012

\begin{tabular}{|c|c|c|c|c|}
\hline No. & Oat genotypes & 2010 & 2011 & 2012 \\
\hline 1. & ARDEN & $2.8 \mathrm{ab}$ & $8.4 \mathrm{cde}$ & \\
\hline 2. & NAGUS n & $3.5 \mathrm{bc}$ & $4.5 \mathrm{a}$ & \\
\hline 3. & DC 1193/04 & $3.0 \mathrm{~b}$ & 5.7abcd & \\
\hline 4. & DC $1329 / 05$ & & $8.8 \mathrm{e}$ & \\
\hline 5. & CHD 2316/03 & $5.7 \mathrm{~d}$ & & \\
\hline 6. & CHD 3047/03 & $3.5 \mathrm{bc}$ & & \\
\hline 7. & DC 1776/04 & & $7.9 \mathrm{bcde}$ & \\
\hline 8. & DC 1832/05 & & & $3,6 a b$ \\
\hline 9. & DC 2112/05 & & & $5,4 \mathrm{~b}$ \\
\hline 10. & DC $2359 / 03$ & & & $4,4 a b$ \\
\hline 11. & DC $239 / 06$ & & & $2,8 \mathrm{ab}$ \\
\hline 12. & DC $3674 / 02 n$ & & & $5,7 \mathrm{~b}$ \\
\hline 13. & POB 648/06 & $1.4 \mathrm{a}$ & & \\
\hline 14. & РOB $1316 / 08$ & $3.5 \mathrm{bc}$ & & $3,5 \mathrm{ab}$ \\
\hline 15. & РOB 1813/08 & $2.9 \mathrm{ab}$ & & \\
\hline 16. & POB 2053/06 & $3.4 \mathrm{bc}$ & & \\
\hline 17. & РОВ 4703-99/08 & $1.7 \mathrm{ab}$ & & \\
\hline 18. & POB 342/09 & & 7.9bcde & \\
\hline 19. & РOB $1882 / 09$ & & $4.7 \mathrm{a}$ & \\
\hline 20. & POB 2085/09 & & $5.5 \mathrm{abc}$ & \\
\hline 21. & РOB 2149/09 & & $8.2 \mathrm{bcde}$ & \\
\hline 22. & POB 158/09 & & $6.5 \mathrm{abcde}$ & \\
\hline 23. & POB $2842 / 08$ & & & $2,9 \mathrm{ab}$ \\
\hline 24. & POB 2885/08 & & & $5,3 \mathrm{~b}$ \\
\hline 25. & POB $3034 / 08$ & & & $3,1 \mathrm{ab}$ \\
\hline 26. & РOB 4129-4416/11 & & & $2,0 \mathrm{a}$ \\
\hline 27. & BINGO & $3.7 \mathrm{bc}$ & 8.6de & \\
\hline 28. & MACZO n & $3.2 \mathrm{bc}$ & $5.2 \mathrm{ab}$ & \\
\hline 29. & Haker & $4.4 \mathrm{~cd}$ & & \\
\hline 30. & STH 8608 & $3.8 \mathrm{bc}$ & & \\
\hline 31. & STH 8809 & $2.8 \mathrm{ab}$ & & \\
\hline 32. & STH 9110 & & $5.3 \mathrm{ab}$ & \\
\hline 33. & STH 9210 & & 7.1abcde & \\
\hline 34. & STH 9410 n & & 8.6de & \\
\hline 35. & STH 0.8124 & & & $5,3 \mathrm{~b}$ \\
\hline 36. & STH 9322 & & & $3,2 \mathrm{ab}$ \\
\hline 37. & STH $0.9403 n$ & & & $4,1 \mathrm{ab}$ \\
\hline 38. & STH $0.9423 n$ & & & $2,9 \mathrm{ab}$ \\
\hline 39. & STH 0.9770 & & & $4,8 \mathrm{ab}$ \\
\hline & Mean & 3.29 & 8.86 & 3.93 \\
\hline
\end{tabular}

Means in columns followed by the same letter are not significantly different at $\mathrm{P} \leq 0.05$

$\mathrm{n}$ - naked oat 
Table 2

Fungi isolated from oat seedlings grown under field conditions in 2010-2012

\begin{tabular}{|c|c|c|c|c|c|c|c|c|c|c|c|c|}
\hline \multirow{3}{*}{ Fungal species } & \multicolumn{11}{|c|}{ Number of isolates $(\%)$} & \multirow{3}{*}{$\begin{array}{c}\text { Total } \\
\text { number of } \\
\text { isolates }\end{array}$} \\
\hline & \multicolumn{3}{|c|}{2010} & \multicolumn{3}{|c|}{2011} & \multicolumn{3}{|c|}{2012} & \multicolumn{2}{|c|}{ Total } & \\
\hline & $\mathrm{r}$ & ls & $\mathrm{r}+\mathrm{ls}$ & $\mathrm{r}$ & ls & $\mathrm{r}+\mathrm{ls}$ & $\mathrm{r}$ & ls & $\mathrm{r}+\mathrm{ls}$ & $\mathrm{r}$ & ls & \\
\hline Fusarium avenaceum (Fr.) Sacc. & - & 2 & $\begin{array}{c}2 \\
(0.38)\end{array}$ & 39 & 86 & $\begin{array}{c}125 \\
(11.92)\end{array}$ & 7 & 53 & $\begin{array}{c}60 \\
(5.57)\end{array}$ & 46 & 141 & $\begin{array}{c}187 \\
(7.04)\end{array}$ \\
\hline $\begin{array}{l}\text { Fusarium crookwellense Burgess, } \\
\text { Nelson \& Tousson }\end{array}$ & - & - & - & - & - & - & - & 2 & $\begin{array}{c}2 \\
(0.19)\end{array}$ & - & 2 & $\begin{array}{c}2 \\
(0.08)\end{array}$ \\
\hline Fusarium culmorum (W. G. Sm.) Sacc. & 4 & 9 & $\begin{array}{c}13 \\
(2.45)\end{array}$ & 128 & 129 & $\begin{array}{c}257 \\
(24.5)\end{array}$ & 76 & 181 & $\begin{array}{c}257 \\
(23.86)\end{array}$ & 208 & 319 & $\begin{array}{c}527 \\
(19.84)\end{array}$ \\
\hline Fusarium equiseti (Corda) Sacc. & 4 & 21 & $\begin{array}{c}25 \\
(4.72)\end{array}$ & 7 & 24 & $\begin{array}{c}31 \\
(2.96)\end{array}$ & - & 5 & $\begin{array}{c}5 \\
(0.46)\end{array}$ & 11 & 50 & $\begin{array}{c}61 \\
(2.30)\end{array}$ \\
\hline Fusarium graminearum Schwabe & - & 1 & $\begin{array}{c}1 \\
(0.19)\end{array}$ & 15 & 17 & $\begin{array}{c}32 \\
(3.05)\end{array}$ & 1 & 3 & $\begin{array}{c}4 \\
(0.37)\end{array}$ & 16 & 21 & $\begin{array}{c}37 \\
(1.39)\end{array}$ \\
\hline Fusarium oxysporum Schl. & 46 & 129 & $\begin{array}{c}175 \\
(33.02)\end{array}$ & 102 & 73 & $\begin{array}{c}175 \\
(16.68)\end{array}$ & 95 & 133 & $\begin{array}{c}228 \\
(21.17)\end{array}$ & 243 & 335 & $\begin{array}{c}578 \\
(21.76)\end{array}$ \\
\hline Fusarium poae (Peck.) Wollenw. & 1 & - & $1(0.19)$ & - & 13 & $\begin{array}{c}13 \\
(1.24)\end{array}$ & 15 & 28 & $\begin{array}{c}43 \\
(3.99)\end{array}$ & 16 & 41 & $\begin{array}{c}57 \\
(2.15)\end{array}$ \\
\hline Fusarium solani (Mart.) Sacc. & 2 & 2 & $\begin{array}{c}4 \\
(0.75)\end{array}$ & 76 & 29 & $\begin{array}{c}105 \\
(10.01)\end{array}$ & 42 & 27 & $\begin{array}{c}69 \\
(6.41)\end{array}$ & 120 & 58 & $\begin{array}{l}178 \\
(6.70)\end{array}$ \\
\hline Fusarium sporotrichioides Sherb. & 9 & 12 & $\begin{array}{c}21 \\
(3.96)\end{array}$ & 8 & - & $\begin{array}{c}8 \\
(0.76)\end{array}$ & 11 & 19 & $\begin{array}{c}30 \\
(2.79)\end{array}$ & 28 & 31 & $\begin{array}{c}59 \\
(2.22)\end{array}$ \\
\hline Other colonies & 174 & 114 & $\begin{array}{c}288 \\
(54.34) \\
\end{array}$ & 117 & 186 & $\begin{array}{c}303 \\
(28.88) \\
\end{array}$ & 188 & 191 & $\begin{array}{c}379 \\
(35.19) \\
\end{array}$ & 479 & 491 & $\begin{array}{c}970 \\
(36.52) \\
\end{array}$ \\
\hline Total & 240 & 290 & 530 & 492 & 557 & 1049 & 435 & 642 & 1077 & 1167 & 1489 & 2656 \\
\hline
\end{tabular}

r-roots

ls-leaf sheaths

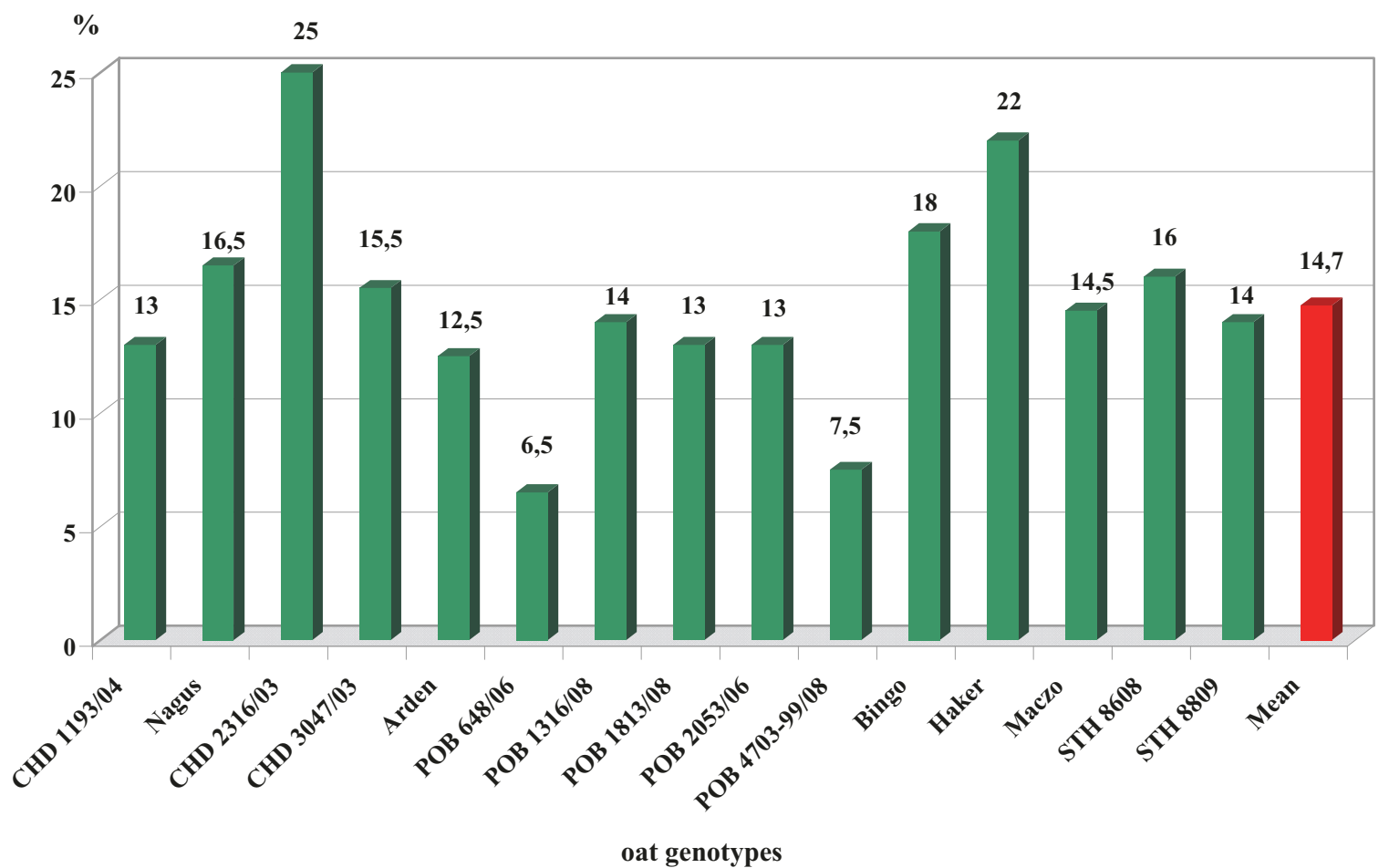

Fig. 1. Percentage of plants with root and leaf sheath necrosis symptoms in 2010. 


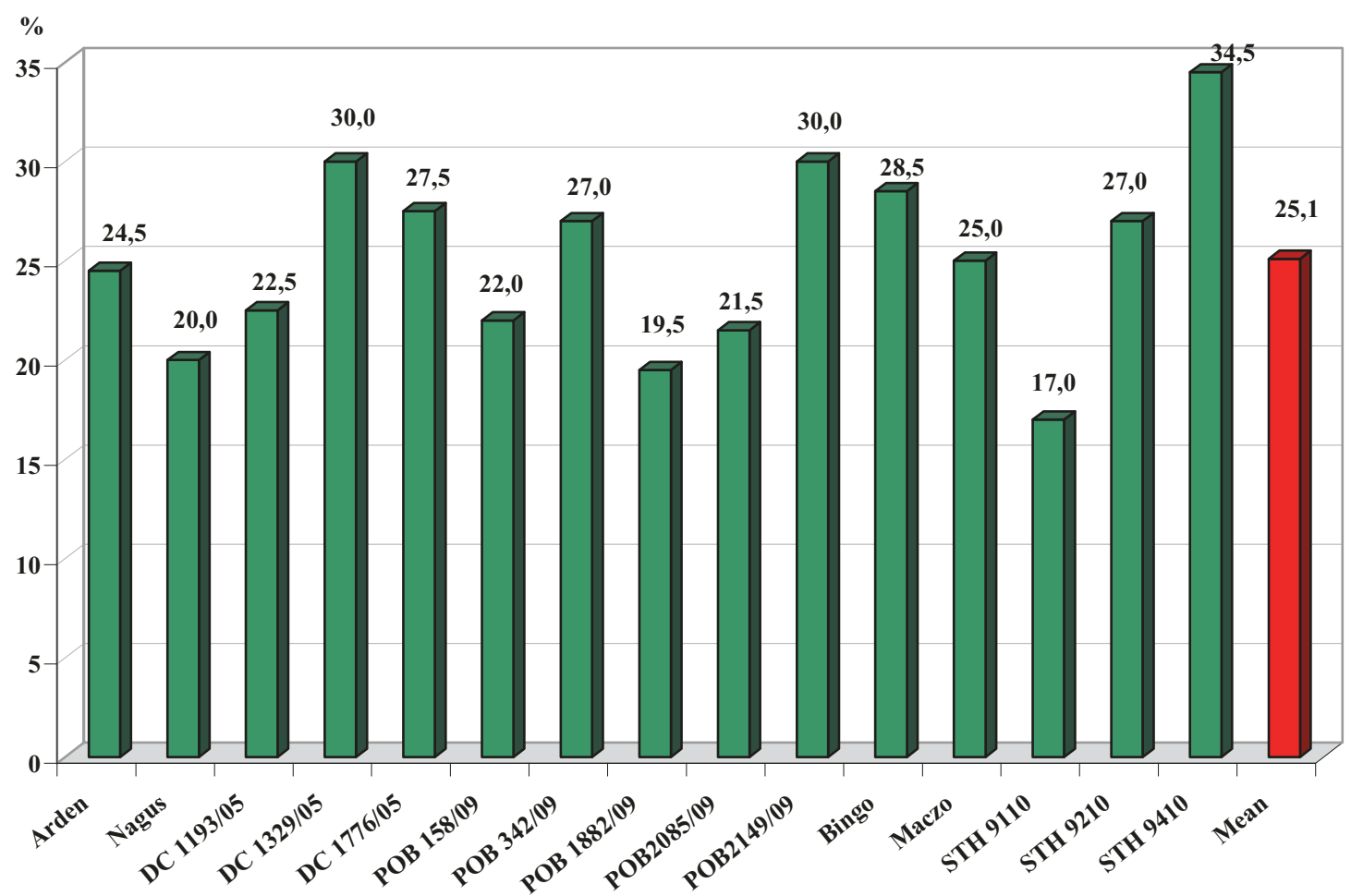

oat genotypes

Fig. 2. Percentage of plants with root and leaf sheath necrosis symptoms in 2011.

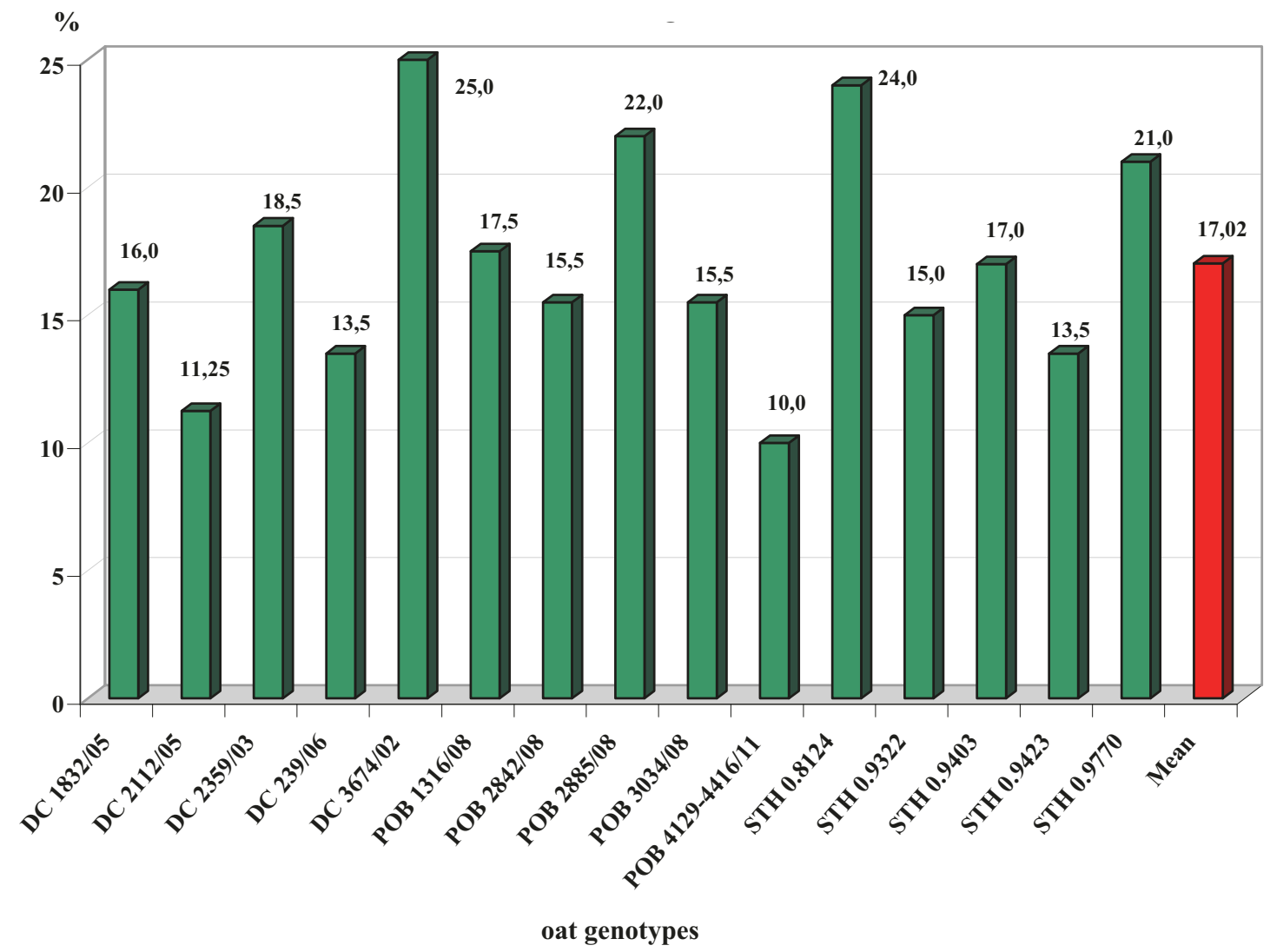

Fig. 3. Percentage of plants with root and leaf sheath necrosis symptoms in 2012. 
On the basis of the statistical analysis of the disease indices, seedlings of the oat genotypes in question were found to show varying susceptibility to infection by the studied strains of Fusarium graminearum. The statistical analysis of the disease indices demonstrated that artificial inoculation of the medium with the $F$. graminearum strain $\mathrm{Tz} 56$ had a significant effect on the health of investigated seedlings compared to the control treatment in the case of all studied oat genotypes (Table 3).

The $F$. graminearum strain $\mathrm{Tz} 56$ proved to be most pathogenic to seedlings of the breeding lines STH 0.9403 and POB 1316/08, for which the disease index was 80.5 and 75.5 , respectively. The lowest pathogenicity of the a.m. strain was found in the case of the genotypes DC 1832/05 and STH 0.9322, for which the disease index was 26.5 and 32.0, respectively (Table 3).
The present study showed that inoculation of the medium with the $F$. graminearum strain Tk 235 also had a significant effect on the infection of oat seedlings in all tested genotypes compared to the control (Table 3).

The $F$. graminearum strain Tk 235 proved to be most pathogenic to the genotypes STH 0.9403 and STH 0.9423, for which the disease index was 70.5 and 70.0 , respectively, while it was least pathogenic to the breeding lines DC 2112/05, POB 4129-4416/11, DC $1832 / 05$ and DC 239/06, in the case of which the disease index was, respectively, 25.5, 26.75, 28.25, and 29.25 (Table 3).

The disease index for seedlings in the control treatment ranged from 0.5 to 2.25 (Table 3).

The mycological analysis of infected oat seedlings indicates that the $F$. graminearum was the cause of pre- and post-emergence damping-off (Table 4).

Table 3

Mean values of the disease index for seedlings of the tested oat genotypes in the experimental treatment with Fusarium graminearum No. Tz 56, F. graminearum, No. Tk 235 and in the control treatment under growth chamber conditions.

\begin{tabular}{|c|c|c|c|}
\hline \multirow{2}{*}{ Oat genotypes } & \multicolumn{3}{|c|}{ Experimental treatment } \\
\hline & $\begin{array}{c}\text { Fusarium graminearum } \\
\text { No. Tz } 56\end{array}$ & $\begin{array}{c}\text { Fusarium graminearum } \\
\text { No. Tk } 235\end{array}$ & Control \\
\hline DC $1832 / 05$ & $26.5^{*} \mathrm{a}$ & $28.25 * \mathrm{a}$ & 1.25 \\
\hline DC $2112 / 05$ & $55.75^{*} \mathrm{bcd}$ & $25.5 * \mathrm{a}$ & 1.25 \\
\hline DC 2359/03 & $49.0 * \mathrm{bc}$ & $51.0 * \mathrm{~cd}$ & 1.75 \\
\hline DC 239/06 & $54.75^{*} \mathrm{bcd}$ & $29.25 * a$ & 0.5 \\
\hline DC $3674 / 02 n$ & $65.25^{*} \mathrm{de}$ & $68.5^{*} \mathrm{ef}$ & 1.25 \\
\hline POB $1316 / 08$ & $75.5^{*} \mathrm{ef}$ & $59.25 *$ def & 1.25 \\
\hline POB 2842/08 & $47.25^{*} \mathrm{~b}$ & $56.75 *$ cde & 1.0 \\
\hline POB 2885/08 & $57.0 * \mathrm{bcd}$ & $50.75 * \mathrm{~cd}$ & 1.5 \\
\hline POB $3034 / 08$ & $49.0 * \mathrm{bc}$ & $35.0 * \mathrm{ab}$ & 1.0 \\
\hline РOB 4129-4416/11 & $49.0 * \mathrm{bc}$ & $26.75 * a$ & 1.75 \\
\hline STH 0.8124 & $54.5^{*}$ bcd & $48.0 * \mathrm{c}$ & 2.25 \\
\hline STH 0.9322 & $32.0 * \mathrm{a}$ & $46.0 * \mathrm{bc}$ & 1.5 \\
\hline STH $0.9403 \mathbf{n}$ & $80.5 * f$ & $70.5 * f$ & 0.5 \\
\hline STH $0.9423 \mathbf{n}$ & $60.0 * \mathrm{~cd}$ & $70.0 * \mathrm{f}$ & 1.0 \\
\hline STH 0.9770 & $51.25 * \mathrm{bc}$ & $53.75 * \mathrm{~cd}$ & 0.75 \\
\hline Mean & 54.32 & 47.95 & 1.23 \\
\hline
\end{tabular}

* Means in lines are significantly different compared to the control at $0 \leq 0.05$

- Means in columns followed by the same letter are not significantly different at $0 \leq 0.05$

$\mathbf{n}$ - naked oat 
Table 4

Fungi isolated from oat seedlings grown in the growth chamber experiment with inoculation of the medium with the Fusarium graminearum strain No. Tz 56 and the F. graminearum strain No. Tk 235 and in the control treatment.

\begin{tabular}{|c|c|c|c|c|}
\hline \multirow{2}{*}{ Fungal species } & \multicolumn{3}{|c|}{ Experimental treatment } & \multirow{2}{*}{$\begin{array}{l}\text { Total number of } \\
\text { isolates }\end{array}$} \\
\hline & $\begin{array}{l}F . \text { graminearum } \\
\text { No. Tz } 56\end{array}$ & $\begin{array}{l}\text { F. graminearum } \\
\text { No. Tk } 235\end{array}$ & Control & \\
\hline Acremonium roseum (Oud.) W. Gams & - & - & 19 & 19 \\
\hline Alternaria alternata (Fr.) Keissler & 6 & 8 & 43 & 57 \\
\hline Aspergillus niger van Tiegh. & 3 & - & - & 3 \\
\hline Bipolaris sorokiniana (Sacc.) Shoemaker & 3 & - & - & 3 \\
\hline Epicoccum nigrum Link & 27 & 2 & 41 & 70 \\
\hline Fusarium culmorum (W.G. Sm.) Sacc. & - & 2 & 15 & 17 \\
\hline Fusarium equiseti (Corda) Sacc. & - & 3 & 6 & 9 \\
\hline Fusarium graminearum Schwabe & 738 & 786 & 7 & 1531 \\
\hline Fusarium oxysporum Schl. & 6 & 6 & 20 & 32 \\
\hline Fusarium poae (Peck.) Wollenw. & - & 2 & 25 & 27 \\
\hline Fusarium sporotrichioides Sherb. & - & - & 24 & 24 \\
\hline Mucor hiemalis Wehmer & 42 & 3 & 10 & 55 \\
\hline Mucor mucedo Fres. & 9 & 6 & - & 15 \\
\hline Penicillium puberulum Bainier & 6 & - & 29 & 35 \\
\hline $\begin{array}{l}\text { Penicillium verrucosum Dierckx var. } \\
\text { cyclopium (Westling.) Samson et al. }\end{array}$ & 18 & 4 & 35 & 57 \\
\hline Rhizopus nigricans Ehrenberg & 6 & - & 20 & 26 \\
\hline Trichoderma aureoviride Rifai & - & - & 11 & 11 \\
\hline Trichoderma harzianum Rifai & - & - & 23 & 23 \\
\hline Trichoderma koningii Oud. & 15 & 8 & 47 & 70 \\
\hline Trichoderma viride Persoon ex S.F. Gray & 23 & 3 & - & 26 \\
\hline Total & 902 & 833 & 375 & 2110 \\
\hline
\end{tabular}

\section{DISCUSSION}

Field observations carried out in central Poland revealed that oat plants with root and leaf sheath necrosis symptoms occurred at a higher percentage than in the case of oat grown in the eastern area of the Lublin region [1].

The species Fusarium culmorum, F. avenaceum and $F$. solani proved to be the cause of damage of oat seedlings in the spring. The pathogenicity of $F$. avenaceum and F.culmorum to oat seedlings has also been confirmed by the research of $\mathrm{Ki} \mathrm{e} \mathrm{c} \mathrm{a} \mathrm{n} \mathrm{a} \mathrm{and} \mathrm{K} \mathrm{o} \mathrm{c} \mathrm{y} \mathrm{-}$ $\nmid$ a k [21] as well as of Mańk a [20]. Fusarium culmorum has been found to show high pathogenicity to seedlings of various cereal species [20, 28, 29].

Secondary metabolites, including deoxynivalenol (DON), participate in the disease process caused by Fusarium culmorum. This metabolite exhibits phytotoxic activity in particular against the coleoptile, shoots and callus tissue of wheat [30]. Moreover, DON reduces the germination capacity of seeds and causes a reduction in the number and length of radicles of wheat seedlings. Reduced germination capacity and growth inhibition in seedlings occur already at a DON concentration of $4 \mu \mathrm{g} / \mathrm{ml}$, whereas the use of a concentration of $25 \mu \mathrm{g} / \mathrm{ml}$ completely inhibits root growth and mitotic activity in the cells of the apical meristems of DON-treated roots. This mycotoxin leads to disturbances in the mitotic division of the meristematic cells of wheat roots [31]. In wheat roots subjected to the effect of DON, these authors observed the occurrence of chromatin bridges in the chromosomes and they also found the occurrence of lagging chromosomes in the anaphase. According to $\mathrm{Pack}$ a [32], DON leads to excessive condensation of chromosomes in the metaphase and anaphase and disturbs the synthesis of proteins making up the microtubules of the karyokinetic spindle. Other secondary metabolites can also participate in the pathogenesis of diseases caused by $F$. culmorum, including culmorin, which can inhibit wheat coleoptile elongation at a concentration from $100 \mu \mathrm{M}$ to $1 \mathrm{mM}[33]$. 
Fusarium avenaceum is considered to be a serious pathogen of cereals, including oat $[1,34,35]$. Moniliformin participates in the pathogenesis of diseases caused by $F$. avenaceum; this mycotoxin affects the permeability of the cytoplasmic membranes and causes disturbances in mitotic cell division [32].

Fusarium solani has contributed to root infection in single cropped oat and in oat mixtures with spring barley and spring triticale as well as in triticale grown with oat. This fungus was the main cause of root damage in winter wheat grown after previous crops such as single cropped oat and oat grown in mixtures [35]. This species is considered to be an important producer of fusaric acid (5-(butyl)-2-pyridinecarboxylic acid) [36], a phytotoxin that destroys the vascular bundles in plants. The strong phytotoxicity of this metabolite to rice seedlings has been proved [33].

Fusarium equiseti belonged to the species isolated from infected oat roots and leaf sheaths. In the study by $\mathrm{Majchrzak}$ et al. [37], this fungus proved to be the main causal agent of 190 infections of wheat roots and had a significant contribution to stem base damage in this plant grown in the conditions of the north-eastern regions of Poland. Fusarium oxysporum, which is not considered to be a pathogen of cereal plants [38], was a species that was isolated in each year of the study.

The results obtained in the growth chamber experiment confirmed the high phytotoxicity of Fusarium graminearum to oat seedlings. Under the studied conditions in which 14-day cultures of the tested F. graminearum strains grown on dextrose-potato medium were used as an inoculum, this method proved effective, since there were seedlings with pre- and post-emergence damping-off in the studied oat genotypes in the experimental treatments with both $F$. graminearum $\mathrm{Tz} 56 \mathrm{ob}-$ tained from grass seed and with $F$. graminearum Tk 235 obtained from grass roots. The present growth chamber study and previous information in the literature indicate the contribution of $F$. graminearum to the damage of cereal seedlings $[10,11]$.

\section{CONCLUSIONS}

1. The species $F$. culmorum and $F$. avenaceum are a threat to oat seedlings grown in central Poland.

2. Due to the high pathogenicity of these species, these pathogens should be taken into account in the breeding of new oat cultivars.

3. The breeding line DC 1832/05 seems to be useful in breeding oat for resistance to $F$. graminearum.

\section{Acknowledgements}

Research conducted in the period 2010-2012 supported by the Ministry of Agriculture and Rural
Development, projects No. HOR hn-078 dec-27/10, HOR hn 801-8/11, and HOR hn 801-1/12.

\section{Author's contributions}

Concept of the study: IK; writing of the manuscript: IK, EM, MC, AP; statistical analysis: MC, EM; mycological analysis: IK, AP, MC, EM; analysis of research results: IK, MC, EM, field research: IK, EM, $\mathrm{MC}, \mathrm{AP}$; experiment in the growth chamber: AP, MC, EM.

\section{REFERENCES}

1. Kiecana I, Mielniczuk E, Cegiełko M, Pszczółkowski P. 2003. Badania nad chorobami podsuszkowymi owsa (Avena sativa $\mathrm{L}$.) z uwzględnieniem temperatury i opadów. / Investigations on root and stem rot diseases of oat (Avena sativa L.) with a special regard to temperature and rainfalls. Acta Agrobot. 56, 1-2: 95-107. (in Polish)

2. Kiecana I, Mielniczuk E, Cegiełko M. 2008. Grzyby porażające korzenie i podstawę źdźbła owsa (Avena sativa $\mathrm{L}$.). / Fungi infecting roots and stem bases in oat (Avena sativa L.). Biul. IHAR 247: 73-79. (in Polish)

3. Kraska P, Mielniczuk E. 2012. The occurrence of fungi on the stem base and roots of spring wheat (Triticum aestivum L.) grown in monoculture depending on tillage systems and catch crops. Acta Agrobot. 65 (1): 79-90.

4. Kurowski TP, Marks M, Orzech K, Kowals k a E. 2008. Stan sanitarny i plonowanie pszenicy ozimej w zależności od sposobu uprawy roli. / Sanitary state and yielding of winter wheat as dependent on soil tillage system. Zesz. Prob. Post. Nauk Rol. 531: 95-103. (in Polish)

5. Lemańczyk G, Sadowski Cz. 2000. The effect of different forecrops on the occurrence of Fusarium spp. in winter wheat rhizosphere. Phytopathol. Pol. 20: 131-138.

6. Adamiak J, Adamiak E. 1999. Plonotwórcza i plonochronna rola owsa w płodozmianach zbożowych. / Yield-forming and crop protecting role of oats in cereal crop rotations. Pamiętnik Puławski - Mat. Konf. 114: 16-21. (in Polish)

7. Kiecana I, Mieln iczuk E.2001. Występowanie Fusarium culmorum (W.G.Sm.) Sacc., Fusarium avenaceum (Fr.) Sacc. oraz Fusarium crookwellense Burgess, Nelson \& Toussoun na rodach hodowalnych owsa (Avena sativa L.). / The occurrence of Fusarium culmorum (W.G.Sm.) Sacc., Fusarium avenaceum (Fr.) Sacc. and Fusarium crookwellense Burgess, Nelson \& Toussoun on oats lines (Avena sativa L.). Acta Agrobot. 64, 1: 83 - 93. (in Polish)

8. Cook R J. 1981. Fusarium diseases of wheat and other small grains in North America. [In:] Nelson P.E., Toussoun T.A. and Cook R.J. (ed.), Diseases, Biology and Taxonomy. The Pensylvania State University Park and London: 39-52.

9. Eacicowa B, Pięta D. 1998. Wpływ temperatury i opadów na udział grzybów w powodowaniu chorób podsuszkowych jęczmienia jarego (Hordeum vulgare L.). / The 
effect of temperature and rainfall on the contribution of fungi to causing root and stem rot diseases in spring barley (Hordeum vulgare L.). Acta Agrobot. 51 (1-2): 51-61. (in Polish)

10. Asran MR, Eraky Amal MI. 2011. Aggressiveness of certain Fusarium graminearum isolates on wheat seedlings and relation with their trichothecene production. Plant. Pathol. J. 10 (1): 36-41. http://dx.doi.org/10.39.23/ ppi.2011.36.41

11. Bacon ChW, Hint on DM.2007. Potential for control of seedling blight of wheat caused by Fusarium graminearum and related species using the bacterial endophyte Bacillus mojavensis. Biocontrol Science and Technology 17 (1/2): 81-94. http://dx.doi.org/10.1080/09583150600937006

12. Bateman GL, Gutteridge RJ, Gherbawy Y, Thomsett MA, Nicholson P. 2007. Infection of stem bases and grains of winter wheat by Fusarium culmorum and $F$. graminearum and effects of tillage method and maize-stalk residues. Plant Pathology 56: 604-615. http:// dx.doi.org/10.1111/J.1365-3059.2007.01577.x

13. Kiecana I, Rachoń L, Mielniczuk E, Szumiło G. 2011. The occurrence of fungi on roots and stem bases of common wheat (Triticum aestivum ssp. vulgare L.) and durum wheat (Triticum durum Desf.) grown under two levels of chemical protection. Acta Agrobot. 64 (3): 93-102.

14. Gjaerum HB, Tjamos EC, Viranyi F. 1988. European Handbook of Plant Diseases. Smith I.M. (ed.). Blackwell Sci. Publ. Oxford London, Edinburgh, Boston, Palo Alto, Melbourne.

15. Sut to n JC. 1982. Epidemiology of wheat blight and maize ear rot caused by Fusarium graminearum. Can. J. Plant Pathol. 4: 195-209.

16. Żu k B . 1989. Biometria stosowana. Państwowe Wydawnictwo Naukowe, Warszawa. (in Polish)

17. Kwaśna H, Chełkowski J, Zajkowski P. 1991. Grzyby (Mycota) Tom XXII., Grzyby niedoskonałe (Deuteromycetes), Strzępczakowe (Hyphomycetales), Gruzełkowate (Tuberculariaceae), Sierpik (Fusarium). Inst. Botaniki PAN Kraków. (in Polish)

18. Leslie JF, Summerell BA. 2006. The Fusarium Laboratory Manual. Blackwell Publishing.

19. Mishra CBP, Behr L. 1976. Der Einfluss von Kulturfiltraten von Fusarium culmorum (W. G. Sm.) Sacc., Fusarium avenaceum (Fr.) Sacc. und Fusarium nivale (Fr.) Ces., Griphosphaeria nivalis Müller et v. Arx auf die Keimung des Weizen. Arch. Phytopathol. Pflazenschutz 12, 6: 373-377. (in German)

20. Mańka M. 1989. Patogeniczność wybranych gatunków z rodzaju Fusarium dla siewek zbóż. / Pathogenicity of selected species from the genus Fusarium to cereal seedlings. Rocz. AR Poznań, Rozp. Nauk. 201: 1-64. (in Polish)

21. Kiec ana I, K oc yłak E. 1999. Pathogenicity of Fusarium spp. on oats seedlings (Avena sativa L.). Plant Breed. Seed Sci. 43, 1: $91-99$.

22. E11 is M B. 1971. Dematiaceous Hyphomycetes. Commonwealth Mycological Institute, Kew Surrey, England.
23. G a m s W. 1971. Cephalosporium - artige Schimmelpilze (Hyphomycetes). Gustav Fischer Verlag, Stuttgart.

24. Ramirez C. 1982. Manual and atlas of the Penicillia. Elsevier Biomedical Press., Oxford.

25. Rifai M A. 1969. A revision of the genus Trichoderma. Kew, Surrey, England.

26. Skirgiełło A, Zadara M, Ławrynowicz M. 1979. Grzyby (Mycota). Tom X. Glonowce (Phycomycetales), Pleśniakowe (Mucorales), Kłebiankowe (Endogonales). Warszawa-Kraków. (in Polish)

27. Thom Ch, Raper K B. 1945. A manual of the Aspergilli Baltimore. The Williams \& Wilkins Company.

28. Kiecana I, Cegiełko M, Mielniczuk E.2009b. Występowanie Fusarium spp. na życie ozimym (Secale cereale L.) i podatność różnych genotypów na porażenie przez F. avenaceum (Fr.) Sacc. i F. culmorum (W.G.Sm.) Sacc. / The occurrence of Fusarium spp. on winter rye (Secale cereale L.) and susceptibility of different genotypes to infection with $F$. avenaceum (Fr.) Sacc. and F. culmorum (W.G.Sm.) Sacc. Biul. IHAR. 252: 151-161. (in Polish)

29. Strausbaugh CA, Bradley CA, Koehn AC, Forster R L. 2004. Survey of root of wheat and barley in southeastern Idaho. Can J Plant Pathol. 26: 167 -176. http:// dx.doi.org/10.1080/07060660409507128

30. Eudes F, Zhou W, Badea A, Laroche A. 2004. Toward the development of Fusarium head blight resistance and reduced levels of mycotoxin in wheat and barley. Recent Res. Develop. Plant Pathol. 3: 17-49.

31. Wiśniewska H, Buśko M. 2005. Evaluation of spring wheat resistance to Fusarium seedling blight. Biologia, Bratislava 60 (3): 287-293.

32. Packa D. 1997. Cytogenetic effect of Fusarium mycotoxins on tip cells of rye (Secale cereale L.), wheat (Triticum aestivum L.) and field bean (Vicia fabe L. Var. Minor). J. Appl. Genet. 38, (3): 259-272.

33. Desjardins AE. 2006. Fusarium mycotoxins, chemistry, genetics, and biology. The American Phytopathological Society St. Paul, Minnesota, U.S.A.

34. Kiecana I, Mielniczuk E, Cegiełko M.2009a. Fungi colonizing grains of oat (Avena sativa L.) grown in the conditions of infection by Fusarium spp. In: "Seed - source of infection". 4th International Seed Health Conference of Seed Pathology Section. Wrocław, Poland 7-9 September 2009. The Polish Phytopathological Society - Section of Seed Pathology, Wrocław University of Environmental and Life Sciences. Book of Abstracts. Wrocław: 25.

35. Lemańczyk G, Wenda-Piesik A, Wasilewsk i P. 2001. Wpływ uprawy owsa w siewie czystym oraz w mieszankach na jego zdrowotność i wartość przedplonową dla pszenicy ozimej. / Impact of the cultivation of oats in mixtures on the health status and yieldding and evaluation of its forecrop value for winter wheat. Fragmenta Agronomica 4 (72): 65-77. (in Polish)

36. Bryden WL, Logrieco A, Hamed K, Abbas HK, Porter JK, Vesonder RF, Richard JL, Cole RJ. 2002. Other significant Fusarium mycotoxins. [In:] Summerell B.A., Leslie J.F., Backhouse D., Bryden W.L., Bur- 
gess L.W. Fusarium Paul E. Nelson Memorial Symposium. APS Press The American Phytopathological Society St. Paul, Minnesota: 360-392.

37. Majchrzak B, Kurowski TP, Okorski A. 2008. Fungi isolated from the roots and stem bases of spring wheat grown after different cruciferous plants as forecrops. Pol. J. Natur. Sc. 23 (2): 299-309.

38. Truszkowska W, Chmurzyńska I, Czyrek A, Dorenda M. 1983. Zagadnienie zgorzeli podstawy źdźbła owsa (Avena sativa L.) w świetle doświadczeń agrotechnicznych. / Problem of foot rot in oats (Avena sativa L.) in the light of field crop production experiments. Rocz. Nauk Rol. ser. E 13, 1-2: 73-82. (in Polish)

\section{Występowanie Fusarium spp.}

na owsie (Avena sativa L.) i podatność siewek wybranych genotypów na porażenie przez Fusarium graminearum Schwabe

\section{Streszczenie}

Badania przeprowadzono w latach 2010-2012 na polach Hodowli Roślin Strzelce Sp. z o. o., Grupa IHAR, objęto nimi 39 genotypów owsa. W fazie 6-tygodniowych siewek oceniano udział roślin z objawami nekrozy korzeni oraz pochew liściowych. Udział sie- wek z objawami chorobowymi wynosił w 2010 roku od $6,5 \%$ do $25 \%$, w 2011 roku od $17 \%$ do $34,5 \%$, zaś w 2012 roku od $10,0 \%$ do $25,0 \%$. Wartości wskaźnika chorobowego wahały się w 2010 roku od 1,4 do 5,7, w 2011 roku od 4,5 do 8,8, zaś w 2012 roku od 2.0 do 5,4. Analiza mykologiczna wykazała, że zarówno z korzeni jak i z pochew liściowych licznie uzyskiwano kolonie Fusarium spp. Izolaty tych grzybów stanowiły 63,48\% ogółu grzybów wyosobnionych z siewek. Przyczyną uszkodzenia siewek owsa uprawianego w warunkach centralnej Polski były gatunki: $F$. culmorum, $F$. avenaceum i $F$. solani. Badania podatności siewek 15 genotypów owsa na porażenie przez dwa szczepy Fusarium graminearum - Tz 56 i Tk 235 przeprowadzono w warunkach fitotronowych, w temperaturze $22-23^{\circ} \mathrm{C}$ i wilgotności względnej powietrza $85 \%$. Szczep $F$. graminearum Tz 56 okazał się najbardziej patogeniczny w stosunku do siewek rodów hodowlanych STH 0.9403 oraz POB 1316/08, dla których wartości wskaźnika chorobowego wynosiły odpowiednio 80,5 oraz 75,5. Najmniejszą szkodliwość w/w szczepu zanotowano w przypadku genotypu DC 1832/05, dla którego wartość wskaźnika chorobowego wynosiła 26,5. Szczep $F$. graminearum Tk 235 okazał sie najbardziej patogeniczny dla genotypów STH 0.9403 i STH 0.9423, dla których wartości wskaźnika chorobowego wynosiły odpowiednio: 70,5 i 70,0, zaś w/w szczep był najmniej patogeniczny dla rodu hodowlanego DC 2112/05, w przypadku którego wartość wskaźnika chorobowego wynosiła 25,5.

Handling Editor: Elżbieta Weryszko-Chmielewska

This is an Open Access digital version of the article distributed under the terms of the Creative Commons Attribution 3.0 License (creativecommons.org/licenses/by/3.0/), which permits redistribution, commercial and non-commercial, provided that the article is properly cited. 